\title{
MERGERS' IMPLICATIONS FOR EMPLOYEES UNDER ROMANIAN LAW
}

\author{
F. Bejan
}

\section{Felicia Bejan}

The Bucharest University of Economic Studies, Department of Law

* Correspondence: The Faculty of Political Science, 24 Sfantul Stefan St., 023997, Bucharest, Romania

E-mail: felicia.bejan@fspub.unibuc.ro

\begin{abstract}
Mergers of enterprises produce profound effects over the rights of associates, creditors, and employees. Although the interests of each of the categories of persons affected are protected by national and European norms, employees enjoy a particular attention. In European law, Directive 2001/23/EC regulates the safeguarding of employees' right in the case of transfer of undertakings, businesses, and parts of undertakings or businesses. Communitarian dispositions have been transposed in Romanian law by articles 173-174 of Law 53/2003 - The Labour Code and Law 67/2006 regarding the protection of employees' rights in the event of transfer of undertakings, businesses, or parts of them, which transpose the Communitarian norms in the subject matter.

The labour contract is an intuitu personae contract, the relationship between employee and employer being one of subordination. Thus, there are at least two rationales that justify the lawmaker's preoccupation for the implications of restructuring operations over employees. Employee protection in case of transfer by merger entails, in substance, the safeguarding of their rights and obligations within the framework of the ceded entity, as they had been set by the labour contract of the cedent entity. The current study critically analyses the national law concerning the transfer of labour contracts in the context of transfer by merger. The paper also contains a number of de lege ferenda proposals, which can contribute to the improving of the existing juridical framework.
\end{abstract}

Keywords: merger, legal transfer, employees, labour contract.

\section{Introduction}

According to Directive 2001/23/EC concerning the safeguarding of the rights of employees in cases of transfers of undertakings, businesses, or parts of them, to be appropriated by member states in national law, transposed by Law 67/2006 ${ }^{2}$, the law has as object to be regulated the conditions in which the employees' rights are protected, as provided for by individual labour contracts and in the collective labour contract that applies, in the case of the transfer of undertaking, business, or parts of undertakings or businesses towards another employer, as a result of a legal transfer or merger, as provided by the law (art. 1).

In our opinion, the division, together with the merger, is part of the scope of Law 67/2006 concerning the protection of employees' rights in cases of transfer of undertakings, businesses, or parts of undertakings or businesses. As a general consideration, there is a juridical identity between mergers and divisions, with the exceptions of the particularities generated by the specifics of each of the two types of operations. The only admissible

\footnotetext{
${ }^{1}$ Published in the Official Journal no. L 82/2001, p. 16-20

${ }^{2}$ Published in the Official Journal of Romania, Part I, no. 276 of 28 March 2006, came into force the date Romania became a member of the European Union.
} 
conclusion is that the juridical texts regarding employee protection applicable to mergers are equally applicable to divisions.

The merger and division of undertakings have as main effect the universal transfer, or the transfer with a universal title, of the patrimony of the participating entities to the beneficiary entities.

As elements of the patrimony subject to universal transfer, the contracts concluded by the absorbed, merged, or divided entities, still in force at the date of the operation, are transferred to the absorbing or beneficiary entities. Exceptions from this rule are contracts concluded intuitu personae character, which are in principle not transferrable. A continuation of contracts belonging to this category can only happen with the agreement of all parties involved.

Labour contracts are parts of the intuitu personae type of juridical acts belonging to the patrimony of a business at the moment of the restructuring operation. The intuitu personae character opposes the transfer of such contracts to the new employer in the absence of consent from the parts to a contrary preference.

Following this logic, the merger or division could constitute cause for termination of the labour contract. It is for this reason that, in order to ensure a stability for the employees of the entities participating in the process, the European legislator had to intervene and institute expressly the exception of the continuity of labour contracts, in spite of their intuitu personae character.

\section{The transferral of labour contracts.}

At national level, the legal transfer of individual and collective labour contracts as effect of mergers and divisions is regulated by articles 173-174 of the Labour Code, and the dispositions of Law 67/2006.

In order for the dispositions of article 173 paragraph 2 from the Labour Code and article 5 paragraph 1 from Law 17/2006 concerning the safeguarding of employee rights to be applied in the case of transfer by merger or division of businesses, the following cumulative conditions need to be met: a legal transfer to actually take place and the labour contracts to be ongoing.

\section{a) A legal transfer to take place.}

The scope of regulating employee protection is to ensure the continuity of labour contracts in the event in which the employing entity is subject to a transfer. The notion of legal transfer of an undertaking, business, or parts of undertakings or businesses, has been the object of numerous interpretations. The Court of Justice conferred a very wide interpretation to the concept. As it was established by the Allen case, essential for defining a transfer is "the change of the private or legal person responsible with undertaking an activity, in whose charge fall the obligations of an employer towards the transferred employees, no matter of whether or not the property right is transferred or not". 3

Consistent with this line of interpretation, national courts have decided that in order to operate a transfer it is sufficient the transfer of an activity of the cedent to the cessionary, without being necessary to transfer the property rights over a determined segment of the assets. $^{4}$

Whichever the juridical nature of the act by which a transfer is realised, in order to determine the real existence of a transfer that would impose the continuation of labour contracts, the following conditions need to be met:

\footnotetext{
${ }^{3}$ Case C-234/98. G. C. Allen and Others v Amalgamated Construction Co. Ltd., http://eurlex.europa.eu

${ }^{4}$ Civil Verdict no. 1257 of 3 December 2007, the Court of Appeal of Alba Iulia County, the Section for labour conflicts and social security. The same ruling showed that, in order to perform a transfer, the agreement of the representing syndicate is not required, nor is the formulation of an additional act to the employees' labour contracts, the only expression of will necessary being that for the completion of the transfer between the cedent and cessionary.
} 
- the business, undertaking, or parts of undertakings or businesses subject to transfer must be an economic entity organized in a stable manner, that is an organized ensemble of people and assets that allow the carrying out of an economic activity

the business, undertaking, or parts of undertakings or businesses subject to transfer, as defined above, must retain its identity, in such a way as to allow the continuation or the restart of activity post-transfer.

The preservation of the economic entity's identity may result from the activity of the employer, of its staff, the organization of labour, the methods of fruition of labour or of production.

In one case, the Court decided that conditions are met for employee protection "even in cases when part of the undertaking or part of the business being ceded does not maintain its organizational structure, condition being that the functional connection between the various transferred means of production be maintained, and that this connection grants the cedent the capacity to use the latter in the framework of a continuation of the economic activity that is identical or analogous". 5

Thus, the identity of a business, undertaking, or part of undertakings or businesses may be retained independently from the preservation or loss of autonomy as a consequence of the transfer.

As an example, it has been shown that, in order to establish whether or not the identity of an entity is retained, national courts have to analyse:

- $\quad$ the type of transfer

- $\quad$ the fixed and current assets that were transferred

- $\quad$ the value of the transferred assets at the time of transfer

- $\quad$ the taking over of labour contracts by the new employer

- $\quad$ the transfer of clients

- $\quad$ the similarities between the activity prior to the transfer and post-transfer

- the potential suspension of activity of the entity prior to transfer and the duration of the suspension ${ }^{6}$

A particular attention must be granted to the fact that the transfer entails, beyond the transfer of tangible or intangible assets, of labour contracts, of clients, the continuation by the cessionary of the same activity or of one that is similar to that of the transferring employer. There can be no continuity of labour contracts in the absence of an activity that employees can undertake according to their qualifications. Claiming the contrary would imply the possibility of future layoffs on grounds of inadequate professional performance on the respective positions.

As it can be determined from the decisions of the Court of Justice, the criterion of preserving the same line of activity in the event of change of employer as qualifier for a transfer should not be taken strictly. The retention of identity of the business entails that the new employer undertakes an economic activity identical or similar.

As such, it is difficult to assume that a private or legal person understands to be part of a legal transfer as cessionary, with the intention to undertake activities that the transferred fixed and current assets, as well as the human capital present cannot sustain. On the other hand, an adjustment of the cessionary's activity to the market demands may generate changes in its main or secondary activity, without implying a radical stray from the initial profile.

Merger and division operations, by their nature, are susceptible to meet the prerequisite conditions for a legal transfer of the business.

\footnotetext{
5 Case C-175 199, Didier Mayeur v Association Promotion de l'information messine (APIM), http://eurlex.europa.eu

${ }^{6}$ Case C-13/95, Suzen, http://eurlex.europa.eu
} 
The commercial entities transferred partially or in their entirety are entities established according to the dispositions of Law 31/1990, and are organized in such a way that the activities they undertake "of a stable manner" are conducive to bringing a profit.

At the same time, what normally motivates a merger or division operation is the need to resize the activity, depending on the market demands and the resources of each participant to the economic environment. It is why any entity that takes over another entity or parts of it is interested in developing the respective activity. This means that, in principle, the identity of the merged, assimilated, or divided entity, may it be by means of merger or division, is retained.

It is however not inconceivable that the cessionary, in good faith, finds itself in the impossibility to maintain an activity identical or analogous, due to objective or subjective factors. At the same time, hypotheses cannot be excluded such that the cessionary may only be interested in the current assets of the cedent entity, or worse, intents to eliminate a competitor from the market.

In other words, if meeting the condition of the stable organization of the cedent entity does not pose a problem, the same cannot be said about the continuation of activity as part of the cessionary entity.

As a consequence, employees' rights may be affected by a potential change of the object of activity of the employer, or by future developments occurring after the transfer takes place. Irrespective of the reasons for which the new employer does not continue the previous activity, it is obvious that the regulations concerning the safeguarding of employee rights cannot protect the employees against every risk.

For such instances as the discontinuation by the new employer of the former activity, the question can be raised whether, in the absence of a transfer in the spirit of the law, the principle of universal transfer of the patrimony can compensate for the protection that the particular law guarantees whenever the warranted conditions are met.

In our opinion, in order to formulate an answer for this particular problem, it is necessary to ground our rationale on the principle of the free will of the parties involved in mergers or divisions, and on the intuitu personae character of the labour contract.

Thus, by virtue of the principle of autonomous will, the assimilated and the newly formed entities, in the case of mergers, respectively the beneficiary entity in the case of divisions, may not be obliged by law to set their object of activity in such a way as to maintain the activity of the assimilated, merged, or divided entities. Consequently, the dispositions of Law 67/2006 are not applicable in the case in which the transfer by merger or division does not fulfil the condition of the continuation of an activity identical or similar.

At the same time, the intuitu personae character of labour contracts opposes the universal transfer of rights and obligations, in the absence of the explicit accord of the parties involved.

In such conditions, the cessionary cannot be obliged to continue the labour contracts of the cedent, should it decide not to undertake an activity identical or similar to that of the cedent. In the eventuality in which, hypothesising, the cessionary would decide to preserve the labour contracts, but not the activity of the cedent, the juridical grounding of the continuation of the contracts is the will of the cessionary expressed by the continuation, and not the principle of universal transfer, and even less the dispositions of Law 67/2006. Furthermore, given these conditions, we are of the opinion that the cessionary and the employees have the freedom to negotiate a modification of the content of the labour contract, in consonance with the activity performed by the employer and considering the professional skills of the employees.

\section{b) The labour contracts must be ongoing}

Per a contrario, the employees whose labour contracts end prior to the date of the merger or of the division cannot benefit from the provisions of the law. 
In other words, in order for the contracts to be preserved by the assimilating, the newly-established, or beneficiary entity, the labour contracts must be part of the current assets of the divided or assimilated business.

If in the case of mergers all the rights and obligations of the assimilated or fused entities that result from the ongoing labour contracts are transferred fully to the assimilating or newly-formed entity, in the case of divisions, respectively of breaking-offs, we have identified several issues.

The first of them refers to the criterion according to which the dividing society distributes the employees between the entities enjoying the results of the division. Similarly, in the case of break-offs, the problem being raised is by virtue of which principle do the habilitated bodies decide which are the employees that will continue their activity in the entity subject to the break-off, and which are those whose rights and obligations shall be transferred to the entities receiving the patrimony of the company being split.

A second issue being raised is whether or not the employees enjoy or not the right to oppose the decision, and the criteria that can be invoked in order to challenge the allocation to one or the other of the employers; and to have the possibility to gain the right to continue their labour contract with that of the employers with which they can demonstrate a clearly outlined relationship, both from an objective as well as subjective points of view.

De lege ferenda, in order for employers to not proceed arbitrarily in their decisions regarding the allocation of employees, the optimal solution is the setting of minimal objective criteria that should be respected.

The legislative consecration of such allocation criteria is all the more important considering how, implicitly, it would significantly limit the potential infringements of employees' rights and, consequently, would reduce the number of cases that could be challenged on grounds of allocation of employees. Also, it would offer the courts of law, if they were to be intimated in such situations, a juridical framework to facilitate the handing down of lawful and sound verdicts.

Up to the creation of such regulations, the decision of allocation of employees remains with the management bodies of the entities involved. We may presume that these will consider with precedence the relationship between the content of the labour contracts of each employee, particularly the details in the job description, and the nature of the activities each of the companies will undertake after completing the transfer. Such a solution responds simultaneously to the interests of the companies, which essentially undertake an activity with the purpose of obtaining profit, purpose towards which the available human capital brings a decisive contribution, but also to the interests of the employees, for which, beyond the economic criterion, particularly considering wages, it is important to be involved in activities consonant with their training, abilities, and professional experience.

Concerning the employee's opposition to the transfer by division, the law does not provide for such a right. In spite of all of this, in practice some situations occur in which, on the grounds of express clauses in the contract, or clause of conscience, the employee may continue their labour contract within the cedent company.

\section{The transfer within the notice period.}

The question being raised is what happens in the circumstances when the merger or division is concluded within the notice period, the notice period reaching its term, practically, after the transfer will have taken place. Are such contracts part of the current assets of the transferred business? And if so, what are in this situation the obligations of the cessionary entity?

In practice, the notice period is a period in which the labour contract continues to produce effect. Yet, obviously, the circumstances of the change of employer while in the notice period, time interval in which the employment relationships will continue, do not grant the employee the right to request that the new employer reconsider the layoff decision. At the same time, nothing prevents the new employer to rehire the previously laid-off employee. 
Under no circumstance will the employee have the capacity to claim the exercise of the rights he/she had by virtue of the individual labour contract, invoking as grounds the dispositions of articles 173-174 of the Labour Code, and of Law 67/2006. In this line of thought, the new contract will be drafted barring new terms, the content agreed upon by both parties, that does not necessarily need to be similar with the previous contract.

\section{Modifying the labour contract.}

The stability of the labour force is ensured precisely by that which both European and national norms have set as goal of protecting, that is, the safeguarding of the employee rights by the new employer, with the same terms set with the former employer through the labour contract.

Still, subject to compliance with the labour contract in force, the transfer may entail a change of the labour conditions. Where such a change to be possible, concerning the foreseen measures and the labour and employment conditions, employees are entitled to be notified in writing and to be consulted through their representatives, with at least 30 days before the date of the transfer, thus respecting the terms provided by the law.

It is expressly provided for in article 8 of Law 67/2006 that, in the event that the employee resigns as a consequence of the significant worsening of the labour conditions, the respective termination is considered to manifest due to the actions of the employer.

Another question being raised is what happens in the event when during negotiations regarding the modifications of the labour contract, modifications unfavourable to employees, an accord is reached by representatives and employer. Is this accord capable of changing the prior solution of committing the employer responsibility and releasing the employer from the constraints of such responsibility?

In our opinion, even if consequent to the consultations between employee representatives and those of the entities involved have reached an agreement, should the changes in the labour conditions be significantly detrimental to the employees, the responsibility of the employer subsists, motivated by the fact the respective termination happened for reasons independent of the employees' persona. It is every employee's right, regardless of the employee representatives' decision, to decide upon the fate of their own contract. Thus, we are of the opinion that the will of the employee's representatives cannot change the consent to continue or to terminate the contract, consent that each employee has the right to express autonomously.

Determining the substantial alteration of the character of the labour contract is a matter of fact, and can be established by comparing the clauses of the cedent's labour contract with the envisioned clauses of the cessionary's contract. One ruling of the Court brought forth the notion that the employee's remuneration substantial reduction, even in case of transfer of a private business to state ownership, and the employee is obliged to submit to national norms concerning public sector employees, constitutes a substantial change of the labour conditions to the disadvantage of the employee. For this reason, a potential termination of the contract by the employee must be considered as the fault of the employer, being held responsible accordingly. In the same line of thought, the Court decided that the change of date for wage payment and its composition falls in the same category of situations modifying substantially the terms of the contract or of the labour contract, even if the amount remains the same.

\section{Termination of the labour contract.}

The interdiction of individual or collective termination of employment is one of the fundamental measures instituted in favour of employees by dispositions of article 173 paragraph 3 of the Labour Code and article 7 of Law 67/2006.

This does not mean that the cedent entity cannot operate contract terminations up to the moment of the merger or division, or by the cessionary entity after that point, but that such a measure cannot have as legal grounding the transfer itself. 
Action to the contrary of these provisions entitles the employee with regards to which the termination of contract was enacted to bring the case to court in order to re-establish the former state of things.

A particular situation that may arise in practice is the situation in which the cedent entity decides to terminate a contract, motivated by the transfer or by other reasons, and the court finds the measure to be illegal and ungrounded.

Given that the new employer, by the principle of universal transfer or the transfer with universal title, substitutes in rights and obligations the previous employer, it is obliged to respect the court's decision. The new employer may find itself in the situation to have to continue the employment relationships with the employee in cause, if a request existed in this sense, and to pay compensations equal to the wages adjusted for inflation, increased and updated, and with the rest of the benefits that the employee enjoyed.

The Romanian law omitted to transpose the communitarian norm concerning the individual or solidary responsibility of successive employers in such situations. In spite of this, according to the Romanian law, there are legal instruments available to the cessionary entity to recuperate and potential prejudice.

As a measure of diligence, though, we consider as necessary that part of the free will agreement concerning the terms of the merger, division respectively, the entities involved to provide a solution addressing atypical cases concerning the transfer of rights and obligations generated by labour contracts, including with regard to potential transitory situations.

As to what the layoff of employees post-transfer it should be said that such a measure may be taken by the new employer, should the legal conditions be met. In practice, however, we encounter situations in which, after a certain amount of time after the transfer of an undertaking or a part of it, in good or bad faith, the new employer decides to stop the activity and dissolve the business. Although the law attempts to guarantee the stability of the labour force in the event of a transfer, the protection of employee rights is not and cannot be absolute.

\section{Conclusions}

Employee protection in case of transfer by merger and division entails, in principle, the safeguarding of rights and obligations by the employees, as set by the labour contracts concluded with the cedent enterprises, as part of the cessionary entity.

Certain conditions must be met in order for those interested to benefit from the dispositions of the law. An important condition is that the operation concerns an entity undertaking an economic activity of a stable manner, and continues its activity after the transfer, thus preserving the stability of the undertaken activity and, implicitly, the stability of the labour force. It is equally important that, at the moment of the completion of the transfer, the labour contracts whose continuity is to be protected to be ongoing. If the existence of labour contracts cannot constitute a matter of controversy unless in exceptional circumstances, establishing the real existence of a transfer continues to be a topic subject to debate and which, as a consequence, is susceptible to lead to a non-uniform implementation of the legal acts on the matter by the member states of the European Union.

The transfer accomplished in full compliance with the provisions of the law charges the cedent and the cessionary employer with the obligation of notifying and consulting with the employee representatives, as a first measure-guaranteeing employee rights protection. The fundamental perspective, employee-side, is that ex lege, their rights and obligations resulting from the individual and collective labour contracts be transferred together with their undertaking, business, or parts of undertakings or businesses to the new employer.

National regulations concerning the post-transfer continuation of employment is not safe from critics. For the employees to benefit from an adequate protection in the event their employer decides to operate structural changes, as previously shown, de lege ferenda, clarifications and additions to the existing legal framework are still necessary. 


\section{Bibliography}

I.T. Stefanescu, Theoretical treatise and the practices of the Labour Code, "Universul Juridic" Publishing House, 2012;

O. Tinca, Critical observations to Law no. 67/2006 regarding the employees' rights protection in the event of transfer of undertakings, businesses, or parts of undertakings or businesses, in "Dreptul" Review, no. 2/2007

I.T. Stefanescu, "The Safeguarding of employees' rights in the event of transfer of undertakings, businesses, or parts of undertakings or businesses, in light of Law no. 67/2006", in ", in "Dreptul” Review, no. 9/2006;

$\mathrm{N}$. Voiculescu, Communitarian law, national law, and the case law concerning employees protection in the event of transfer of enterprise, in "Revista Română de Dreptul Muncii” Review, no. 1/2006;

Civil Verdict no. 1257 of 3 December 2007, the Court of Appeal of Alba Iulia County, the Section for labour conflicts and social security;

Case C-175 /99, Didier Mayeur v Association Promotion de l'information messine (APIM), http://eurlex.europa.eu;

Case C-234/98. G. C. Allen and Others v Amalgamated Construction Co. Ltd., http://eurlex.europa.eu;

Case C-13/95, Suzen, http://eurlex.europa.eu;

Law no. 67/2006 regarding the transfer of undertakings, businesses, or parts of undertakings or businesses

Directive 2001/23/EC of the Council of 12 March 2001, regarding the safeguarding of workers' rights in case of transfer of undertakings, businesses, or parts of undertakings or businesses. 